\title{
Optimization of Injection Timing and Injection Duration of a Diesel Engine Running on Pure Biodiesel SME (Soya Methyl Ester)
}

\author{
Abdullah Alghafis, Eihab A. Raouf \\ Mechanical Engineering Department, Unaizah Engineering College, Qassim University, Unaizah, KSA \\ Email: A.alghafis@qu.edu.sa
}

How to cite this paper: Alghafis, A. and Raouf, E.A. (2020) Optimization of Injection Timing and Injection Duration of a Diesel Engine Running on Pure Biodiesel SME (Soya Methyl Ester). Open Journal of Applied Sciences, 10, 486-502.

https://doi.org/10.4236/ojapps.2020.107034

Received: May 27, 2020

Accepted: July 26, 2020

Published: July 29, 2020

Copyright (c) 2020 by author(s) and Scientific Research Publishing Inc. This work is licensed under the Creative Commons Attribution International License (CC BY 4.0).

http://creativecommons.org/licenses/by/4.0/

\begin{abstract}
This study was carried out to predict the impact of injection timing and injection duration on engine brake power and Nitrogen Oxides emissions in a diesel engine using biofuel Soya Methyl Ester (SME). Predictions were accomplished at three different injection timings $10^{\circ}, 5^{\circ}$ Crank Angle (CA) before Top Dead Center (bTDC) and $0^{\circ} \mathrm{CA}$ at Top Dead Center (TDC) and four injection durations $20^{\circ}, 25^{\circ}, 30^{\circ}, 35^{\circ} \mathrm{CA}$. The study was conducted using a simulation software (Diesel-RK). The predicted results showed that the powers produced by all the setups of the different injection timings are almost equal, but they differ in injection durations, e.g. the power at setup (10 $\mathrm{CA}-\mathrm{bTDC})$ duration $20^{\circ} \mathrm{CA}$ and $2500 \mathrm{rpm}$ equal to $52 \mathrm{~kW}$, at setup ( $5^{\circ} \mathrm{CA}-\mathrm{bTDC}$ ) duration $25^{\circ} \mathrm{CA}$ and same engine speed the power is equal to $51 \mathrm{~kW}$, and at setup $\left(0^{\circ} \mathrm{CA}-\mathrm{TDC}\right)$ durations $30^{\circ}$ the power is equal to $51 \mathrm{~kW}$. The power in all setups are decreased as the injection duration increased, e.g. at setup $0^{\circ} \mathrm{CA}$ TDC durations $25^{\circ}, 35^{\circ}$, and $40^{\circ} \mathrm{CA}$ and at $4000 \mathrm{rpm}$, the brake powers are equal 71,65 , and $59 \mathrm{~kW}$ respectively, thus the reduction percentages are $9 \%$ and $17 \%$ when compared to the $25^{\circ}$ injection duration. The nitrogen oxides emissions decreased as the injection duration is increased, e.g. the emissions at setup $\left(10^{\circ} \mathrm{CA}-\mathrm{bTDC}\right)$ durations $25^{\circ}, 30^{\circ}$, and $40^{\circ} \mathrm{CA}$ and at $2500 \mathrm{rpm}$ are equal $852,589,293 \mathrm{ppm}$ respectively, the reduction percentages are $30 \%$ and $72 \%$. The variations of injection timing and injection duration have taken a weighty influence on engine performance and emissions. The results are considered as a novelty in the field of using pure biofuel Soya Methyl Ester in diesel engine according to our information.
\end{abstract}

\section{Keywords}

Pure Biofuel Soya Methyl Ester, Diesel Engine, Injection Timing, Injection Duration Optimization 


\section{Introduction}

Biodiesel is a renewable and an alternative fuel like fossil diesel that can be produced from plant oils, animal grease, or restaurant used oil. Biodiesel is used in diesel engines as an alternative fuel or in any device that works on diesel fuel. Biodiesel physical properties are similar to those of fossil diesel [1] [2]. Biodiesel has ecological benefits, economically inexpensive and can be produced in bulky amounts without decreasing food supplies. Biodiesel shows a number of benefits such as better lubricity which decreases friction and retains equipment well lubricated. It also provides an effective combustion at high temperatures because it uses its own oxygen, and also reduces harmful emissions [3] [4] [5]. The chemical structure in biodiesel and fossil diesel is different, but has similar size of molecules, whereas biodiesel contains no sulfur. Biodiesel contains higher oxygen $10 \%$ to $12 \%$ more than fossil diesel. Also, biodiesel is greatly less toxic than fossil diesel, which is considered as an extra benefit [6].

\section{Literature Review}

The diesel engine performance is deeply affected by the injection system design and profile. In reality, the most distinguished advances attained in diesel engines resulted directly from excellent fuel injection system designs. Whereas the main objective of the fuel system is to provide fuel into the cylinders of a diesel engine, the difference in engine emissions, performance and noise characteristics depends mainly on how that fuel is supplied and delivered to the engine, so as the engine to use the fuel efficiently. The two main purposes of the fuel system are the injection of fuel, must be at an accurate time and sufficient duration, so it is essential to governor the injection timing. The other purpose concern to power requirements, the fuel system must deliver the correct amount of fuel, so it is important to control and metering the injection quantity [7]. The period of time at which the diesel fuel injected into the combustion chamber from the injector is known as injection duration, is the time taken between start of injection and end of injection and is associated with the quantity of fuel injection. Injection timing is the instant of entering the diesel fuel into the cylinder during the burning process [8]. When altering the timing of fuel injection, therefore will lead to change the combustion timing, injection timing has a strong impact on combustion process injection pressure and engine emissions. Some problems occur when the injection system is not properly adjustment, such as difficult starting, hot engine temperature, poor fuel economy, and also smoke during startups and acceleration [9]. The time injection is the most significant parameter to obtain great combustion efficiency, the leading causes to optimize the combustion process are ignition timing and valve opening timing, those in turn affect the engine performance. Crank angle (CA refers to the position of a piston as it moves inside the cylinder with respect to crank shaft rotation) controls essentially fuel injection timing at which combustion starts, thus the combustion efficiency changes as fuel injection advanced or delayed [10]. Delayed injection 
timing (starts later), in this case, the air pressure and temperature are a little higher, and this leads to ignition delay. Advanced injection timing (starts earlier), foremost pressure and temperature of air are lower, thus increase the ignition delay [11]. Consequently, injection timing has a strong influence on the delay of the ignition, and therefore on engine emissions and combustion because the engine maximum temperature and pressure changed. To improve combustion efficiency, injection duration could be reduced with high injection pressures and small nozzles, this is common in the modern Diesel engine [12]. The injector parameters affect the combustion pressure rate, heat release rate, pressure load and pressure oscillation which influences the combustion noise. Nozzle geometry, droplets diameter, mass flow, impulse and angle of spray are the important injection parameters since they are required for excellent fuel evaporation in the combustion chamber. Elements that intensely influence the injection and combustion process are injection pressure, fuel injection timing, the interaction between the fuel injects and airflow in the combustion chamber, the usage of multiple injections and the rate [13]. Therefore, an investigation about the variation of injection timing and injection duration linked to combustion process and exhaust gas emissions are necessary. Furthermore, it was required to discover the best injection timing.

\subsection{Scope of Biodiesel as an Alternative Fuel}

Therefore, in this paper, different injection timing for diesel engine using Biodiesel SME is chosen to optimize the engine performance and emissions. Biodiesel is the likely substitute diesel fuels, is act as an alternate fuel alike to fossil diesel. Biodiesel is able to produce from conventional vegetable oil, animal oil and fats, and unwanted cooking oil. Transesterification is known as a method of converting these oils to Biodiesel. The main likely source of appropriate oil, derives from oil crops such as soybean, rapeseed and palm. Soya Methyl Ester (SME) is a methyl ester derivative from soybean oil. Soy Methyl Ester characteristics are active solvency, volatile organic compounds are low, flashpoint is high, nonhazardous, and friendly with plastics, elastomers, most metals and other organic solvents [14]. Soy Methyl Ester uses as a lubricity element in diesel fuel for alternatives environmentally safe and acts as an economical cleaning agent [15].

There are many environmental benefits of biofuels, the main benefit can be referred to carbon neutral. The biofuels emit at low level a carbon in the form of carbon dioxide $\left(\mathrm{CO}_{2}\right)$, because the grows of oil crop take in an equal quantity of $\mathrm{CO}_{2}$ as is released when the fuel is burned. According to information by the (NREL), biodiesel emits $75 \%$ less $\mathrm{CO}_{2}$ than fossil fuel. Biofuels is a clean fuel when compared to the fossil fuels, produce no sulfur or aromatics during combustion, thus there's no hateful smell related to the biofuels burning. Biofuels are safer and decreases danger of environmental disasters, In Gulf of Mexico, in 2010, an underwater well of oil burst, it released millions of gallons of oil, caus- 
ing an indefinite amount of damage [16]. The biofuels can supply a useful solution to the international petroleum crisis. Bioethanol and biodiesel are the two worldwide biofuels that might replace the fossil fuel. Similar as fossil fuels, biofuels have some environmental effects beside their impacts on greenhouse gas emissions [17]. Comparative to fossil fuels, however, the influences causing from refining, transporting and using biofuels are mostly significantly lesser. Furthermore, there are methods to develop the resource efficiency and impacts of these activities [18] [19]. One of the greatest significant challenges that face engines designers and manufacturers is to decrease the engine emissions by keeping or even improving the engine performance and fuel consumption. Presentday engine suffers from high exhaust emissions, low power output and comparatively high noise during combustion [20]. Different techniques have been carried out in the latest years to achieve the goal of reduction pollutant emissions and improve engine performance such as [21].

1) Directly affecting combustion efficiency

- Recirculation of exhaust gas (EGR).

- Improving the injection system.

- Modifying piston design and combustion chamber.

2) Exhaust gas treatment methods

- Particulate matter filters.

- Diesel oxidation catalysts (DOC) or selective catalytic reduction (SCR) systems.

The objective of this research is to investigate the effect of different injection timing and injection duration of diesel engine running biodiesel on brake power and NOx emissions using an engine simulation software. Examinations will be conducted to select the optimum injection timing condition, and followed by an investigation to find out the best injection duration. The best conditions are selected referring to the maximum obtainable brake power with lesser NOx emissions. To the best of our knowledge, no research was conducted to examine and optimize the best injection timing and injection duration when diesel engine use $100 \%$ biodiesel Soya Methyl Ester, we think it an important gap to be explored.

\subsection{Research Approach}

The study was performed by using diesel-RK simulation software. The selected operating conditions of the engine are as follow:

- At different engine speeds (1000, 1500, 2000, 2500, 3000 and $4000 \mathrm{rpm}$ ).

- At different injection timing $10^{\circ} \mathrm{CA}-\mathrm{bTDC}, 5^{\circ} \mathrm{CA}-\mathrm{bTDC}$ and $0^{\circ} \mathrm{CA}-\mathrm{TDC}$.

- At different injection duration $20^{\circ}, 25^{\circ}, 30^{\circ}, 35^{\circ}$ and $40^{\circ} \mathrm{CA}$.

\section{Methodology}

Diesel-RK Russian simulation software initiated in 1982 in the department of Internal Combustion Engines (Piston Engines), Bauman Moscow State Technical University (MSTU). The software was created as a research improvement tool 
in the field of internal combustion engines. According to the requests of manufacturing enterprises including largest IC engine manufacturers in Russia several computational improvements were done in the software to make it more powerful as an analytical tool [22].

Diesel-RK is a professional software product that can be used effectively by researchers and graduate students. The software has been continuously developed using advanced mathematical models of combustion in a diesel engine. Diesel-RK takes into consideration specific injection parameters and quality of fuel injection, dynamics of diesel fuel inject development, interaction of sprays with air swirl and with cylinder walls and direction of sprays in the combustion chamber [22]. The Diesel-RK software supports some types of engines such as DI Diesel engines, SI petrol engines, SI gas engines, Two-stroke engines and Dual fuel engines. Furthermore, Diesel-RK simulates the shape of combustion chamber, the injection location (central or non-central), numbers, bore and direction of injection, fuels including biofuels and biofuels-diesel mixture, character of injection shape and sprays interaction with cylinder wall [22].

\subsection{Diesel Engine Specifications}

The 4D56 engine is a four-cylinder, belt-driven, overhead camshaft diesel engine, which was a part of the "Astron" family introduced in 1990. As the first Turbo diesel to be offered in a Japanese passenger car. Until now it is still in production, but made into a modern power plant by putting a common rail direct injection fuel system into the engine. The investigations were performed in 4D56 engine with the specifications presented in Table 1 [23].

\subsection{Properties of Biofuel}

Biofuel SME B100 can be used in many different concentrations. The most common are B5 (5\% biodiesel), B20 (20\% biodiesel) and B100 (100\% biodiesel). Using pure biodiesel, a number of issues should be considered. Pure biodiesel contains less energy on a volumetric basis than pure diesel. Therefore, the higher the percentage of biodiesel (above 20\%), the lower the energy content per gallon. To avoid engine operational problems, B100 must meet the specifications of ASTM D6751-15ce1, the properties of the biofuel (B100) are shown in Table 2.

The engine brake power and NOx emissions data, which were obtained as the result of the computer simulation processes are listed in Appendix A. The simulation program was run on the 4D56 diesel engine using Biodiesel SME fuel at different injection timings and durations, to calculate the engine performance and NOx emissions. Firstly, the Diesel-RK software effectiveness could be examined by compares the engine maximum output power (98 $\mathrm{kW}$ at $6400 \mathrm{rpm}$ ) when using diesel as a fuel, with the average power gained by the program at the same engine speed, which is equal to $103.2 \mathrm{~kW}$. The program effectiveness percentage between those values is equal 95\%, while the maximum brake power gained by the software is found at $7000 \mathrm{rpm}$ and is equal to $105.5 \mathrm{~kW}$. This is the justification of choosing the Diesel-RK software as a tool uses in this research. 
Table 1. Specifications of 4D56 diesel engine [23].

\begin{tabular}{ccc}
\hline S/No. & Specification & Value \\
\hline 1 & Number of cylinders & 4 \\
2 & Numbers of valve per cylinder & 16 \\
3 & Combustion Chamber & Pentroof Type \\
4 & Fuel System & Electronic Common Rail direct injection \\
5 & Displacement, $\mathrm{cm}^{3}$ & 2477 \\
6 & Bore $\times$ Stroke, mm & $90 \times 95$ \\
7 & Compression Ratio & $18: 1$ \\
8 & Max Output & $98 \mathrm{~kW}$ at $6400 \mathrm{rpm}$ \\
9 & Max Torque & $174 \mathrm{~N} . \mathrm{m}$ at $4400 \mathrm{rpm}$ \\
10 & Number of injector per cylinder & 0.16 \\
11 & Injector nozzle bore, mm & 3 \\
12 & Number of spray hole/nozzle & 1 bar, $313 \mathrm{~K}$ \\
13 & Ambient parameters & \\
\hline
\end{tabular}

Table 2. Properties of biofuel (SME B100).

\begin{tabular}{ccc}
\hline S/No. & Quantity & Value \\
\hline 1 & Composition (mass fraction) & $\mathrm{C}=0.7731, \mathrm{H}=0.1188$ and $\mathrm{O}=0.1081$ \\
2 & Low heating value $(\mathrm{MJ} / \mathrm{kg})$ & 36.22 \\
3 & Cetane Number & 51.3 \\
4 & Density at $323 \mathrm{~K}\left(\mathrm{~kg} / \mathrm{m}^{3}\right)$ & 885 \\
5 & Surface tension factor at $323 \mathrm{~K}(\mathrm{~N} / \mathrm{m})$ & 0.0433 \\
6 & Specific vaporization heat $(\mathrm{kJ} / \mathrm{kg})$ & 325 \\
7 & Fuel thermal specific capacity $(\mathrm{J} / \mathrm{kg} . \mathrm{K})$ & 1853 \\
8 & Molecular mass & 292.2 \\
9 & Sulphur content & $0.005 \%$ \\
\hline
\end{tabular}

\section{Results and Discussions}

\subsection{Brake Power}

In this section, a brief discussion will be carried out for all results obtained using simulation software. The most interesting parameter of the diesel engine that will be discussed is the engine Brake Power (bp). Brake power is an engine's power output after subtracting the losses caused by auxiliary components (gearbox, alternator, water pump, differential, and other). It is well known that injection timing affects the performance of engine. Injection timing is known as the starting time of injection of diesel fuel into the cylinder, while the injection duration is the interval of time from the start of injection to the end of injection during which the diesel fuel enters the combustion chamber through the injector.

The injection of biodiesel SME at different injection timings and different injection durations are shown in Figures 1-3. Injection timing at $10^{\circ}$ CA-bTDC $\left(10^{\circ}\right.$ before TDC) and at different injection duration $\left(20^{\circ}, 25^{\circ}, 30^{\circ}, 35^{\circ}\right.$ and $\left.40^{\circ}\right)$ 
are shown (see Figure 1), while the injection timing at $5^{\circ}$ CA-bTDC and at different injection duration $\left(25^{\circ}, 30^{\circ}, 35^{\circ}, 40^{\circ}\right.$ and $\left.45^{\circ}\right)$ are presented (see Figure 2 ), and the injection timing at $0^{\circ} \mathrm{CA}$ (at TDC) and at different injection duration $\left(25^{\circ}, 30^{\circ}, 35^{\circ}, 40^{\circ}\right.$ and $\left.45^{\circ}\right)$ are displayed (see Figure 3 ).

In the case of injection timing at $10^{\circ} \mathrm{CA}-\mathrm{bTDC}$ and injection duration $\left(20^{\circ}\right.$, $25^{\circ}, 30^{\circ}, 35^{\circ}$ and $40^{\circ}$ ) (see Figure 1 ), it seems clearly higher brake power obtained at injection timing $10^{\circ} \mathrm{CA}-\mathrm{bTDC}$ and $20^{\circ}$ duration $\left(10^{\circ} \mathrm{-bTDC}\right.$ to $10^{\circ}$ CA-aTDC) at all engine speeds when compared to other injection duration and at same timing. For example, at setup $\left(10^{\circ}\right.$-bTDC to $30^{\circ} \mathrm{CA}$-aTDC) which indicates to $40^{\circ}$ injection duration and $3000 \mathrm{rpm}$ the brake power is equal to 47.923 $\mathrm{kW}$, at setup $10^{\circ}$-bTDC to $10^{\circ} \mathrm{CA}$-aTDC (which refer to $20^{\circ}$ of injection duration) and $3000 \mathrm{rpm}$ the brake power is found to be $61.073 \mathrm{~kW}$, the increasing rate is about $27 \%$ when compared to the $\left(-10^{\circ}\right.$ to $\left.30^{\circ} \mathrm{CA}\right)$ setup, thus the brake power increases as the injection duration decreases from $40^{\circ}$ to $20^{\circ}$ injection duration.

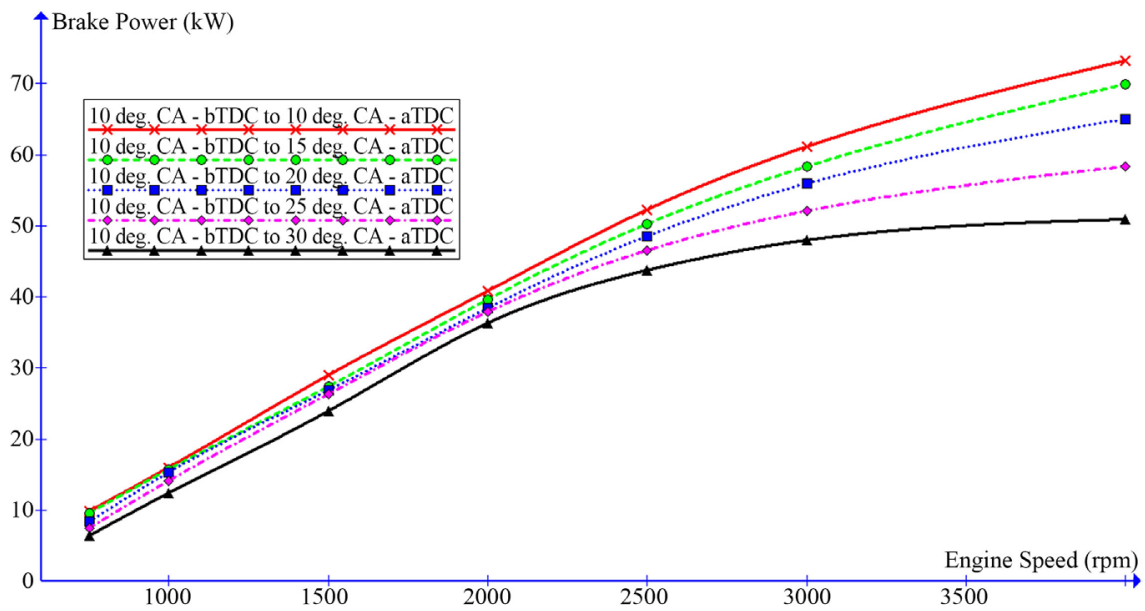

Figure 1. Brake power vs engine speed at timing $10^{\circ} \mathrm{CA}-\mathrm{bTDC}$ and different injection durations.

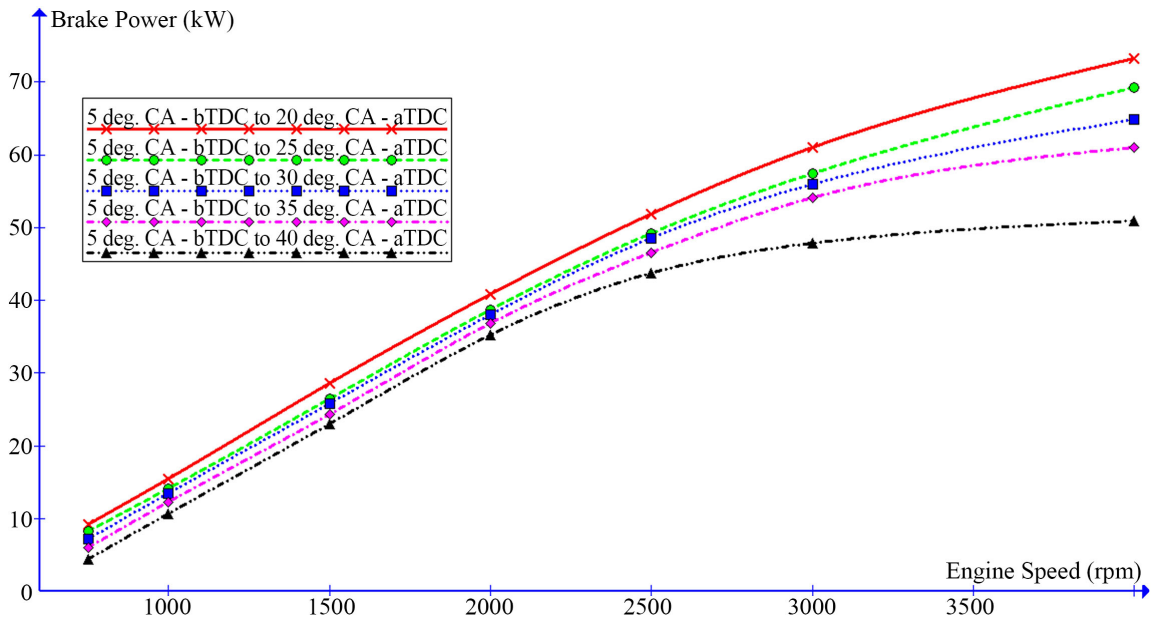

Figure 2. Brake power vs engine speed at timing $5^{\circ}$ CA-bTDC and different injection durations. 


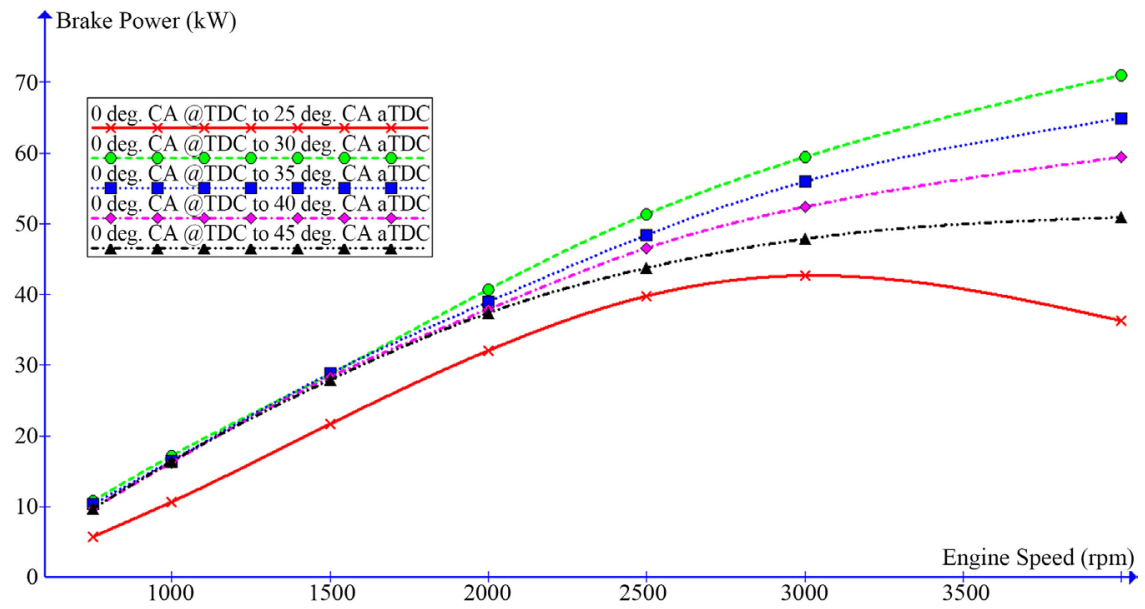

Figure 3. Brake power vs engine speed at timing $0^{\circ} \mathrm{CA}-\mathrm{TDC}$ and different injection durations.

The setup $5^{\circ}$-bTDC to $20^{\circ}$-aTDC ( $25^{\circ}$ of injection duration) obtains the best condition to generate brake power at all engine speeds when compared to the other setups (see Figure 2). The brake power at setups $-10^{\circ} \mathrm{CA}$ to $20^{\circ}$ and $5^{\circ}$-bTDC to $20^{\circ}$-aTDC (both obtain higher brake power) at $4000 \mathrm{rpm}$ are equal to $73.267 \mathrm{~kW}$ and $73.277 \mathrm{~kW}$ respectively. The comparison concludes that the power gained when retarding injection timing $10^{\circ} \mathrm{CA}$ before top dead center with $30^{\circ}$ injection duration at setup $-10^{\circ}$ to $20^{\circ} \mathrm{CA}$ equals to the power gained when retarding injection timing 5o CA before top dead center with injection duration $25^{\circ}$ at setup $5^{\circ}$-bTDC to $20^{\circ} \mathrm{CA}$-bTDC. Little bit difference with $0^{\circ}$ to $30^{\circ} \mathrm{CA}$ setup in brake power which is equal to $70.908 \mathrm{~kW}$ when compare to the earlier setups.

At low and mid-engine speeds the injection duration does not affect the value the brake power significantly (see Figures 1-3), which affects greatly during high speeds. For example, from Figure 1, at setup $0^{\circ}$ to $40^{\circ}$ (injection starting at $0^{\circ}$ $\mathrm{CA}$ and $45^{\circ}$ injection duration) and $1500 \mathrm{rpm}$ the brake power is equal to 27.944 $\mathrm{kW}$, while the brake power at the setup $0^{\circ}$ to $30^{\circ}$ and same engine speed is equal to $28.699 \mathrm{~kW}$, about $2.7 \%$ increasing rate when compared to the $0^{\circ}$ to $40^{\circ}$ setup.

The three best attainable brake power gained from different injection timings and duration are shown in Figure 4. At the first condition, the injection timing starts at $10^{\circ} \mathrm{CA}$ before TDC and $20^{\circ} \mathrm{CA}$ injection duration. The second condition the injection timing starts at $5^{\circ} \mathrm{CA}$ before TDC and $25^{\circ} \mathrm{CA}$ injection duration, while in the third condition the injection starts at the top dead center $0^{\circ} \mathrm{CA}$ and the injection duration takes $30^{\circ} \mathrm{CA}$. Referring to Figure 4, the maximum brake power that can be obtained from using biofuel SME in a diesel engine is by using the setups $10^{\circ}$-bTDC to $10^{\circ}\left(20^{\circ} \mathrm{CA}\right.$ duration) and $5^{\circ}$-bTDC to $20^{\circ}$-aTDC $\left(25^{\circ} \mathrm{CA}\right.$ duration). The third setup $0^{\circ}$-TDC to $30^{\circ}$-aTDC $\left(30^{\circ} \mathrm{CA}\right.$ duration) achieved greater brake power at low engine speeds (less than $2000 \mathrm{rpm}$ ) when compared to the others, while generated less at high engine speeds (more than $2500 \mathrm{rpm}$ ), this reduction is due to the ignition delay (the injection starts at the peak pressure at TDC). 


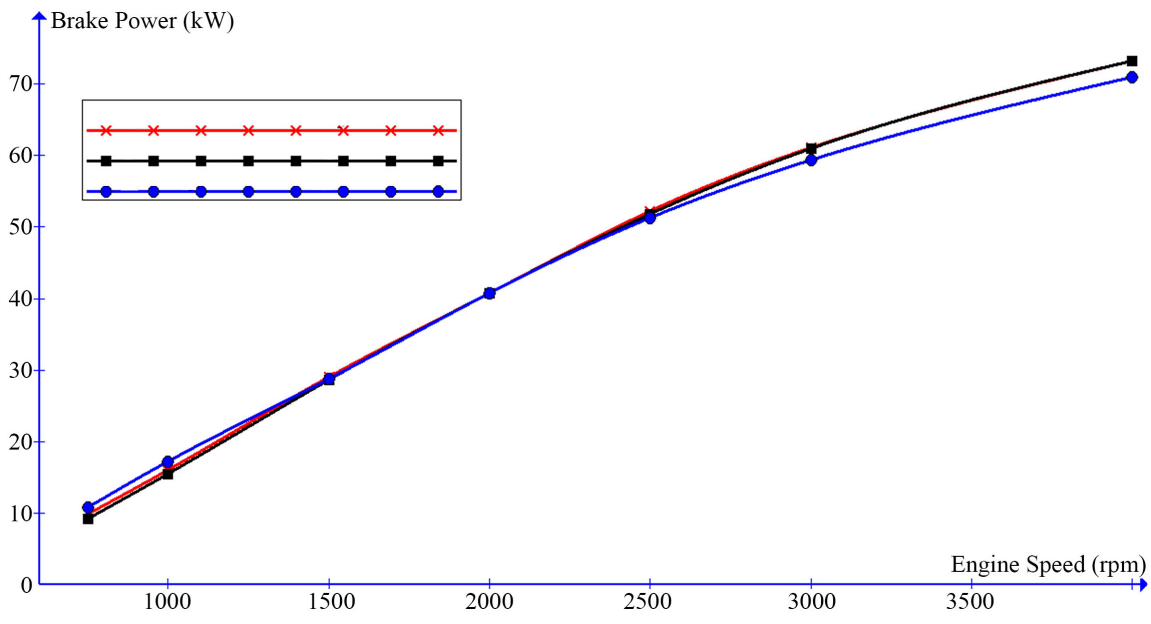

Figure 4. Brake power vs engine speed at timing $0^{\circ} \mathrm{CA}-\mathrm{TDC}, 5^{\circ} \mathrm{CA}-\mathrm{bTDC}$ and $10^{\circ}$ CA-bTDC and different injection durations.

\subsection{Nitrogen Oxides Emission}

In low engine speeds, the operating conditions cause of high nitrogen oxides emissions. At low speeds (750 - $2500 \mathrm{rpm}$ ) and at all operating conditions, engine releases high rates of nitrogen oxides (see Figures 5-7). In low engine speeds, the time for NOx formation is available in addition of availability of excess fresh air $\left(\mathrm{N}_{2}\right.$ and $\left.\mathrm{O}_{2}\right)$ high volumetric efficiency and the temperatures above $1800^{\circ} \mathrm{C}$, all these factors lead to increase the NOx production. On the other hand, the NOx emission is reduced considerably at high engine speeds, as a result of less amount of fresh air entering the cylinder, due to low volumetric efficiency, and less time available for NOx formation. For example, Figure 5 shows, at setup $\left(0^{\circ} \mathrm{CA}-\mathrm{TDC}\right.$ to $\left.25^{\circ} \mathrm{CA}-\mathrm{aTDC}\right)$ and at $750 \mathrm{rpm}$ the NOx is equal to $2267 \mathrm{ppm}$, in the case of $4000 \mathrm{rpm}$ and same setup the NOx decreased to 686 $\mathrm{ppm}$, reduction rate about $30 \%$ due to increase in engine speed.

The highest rate of emissions occurred in the shortage injection duration $\left(0^{\circ}\right.$ $\mathrm{CA}$ to $25^{\circ} \mathrm{CA}$-aTDC) equals to $25^{\circ} \mathrm{CA}$ when the injection starts at $0^{\circ} \mathrm{CA}$ (the piston at TDC) (see Figure 5), whereas the brake power at the same setup reached to its maximum value (see Figure 2). Therefore, a strong relation between the values of brake power and the formation of NOx emissions, as the power increase the NOx increase and vice versa. This phenomenon occurred clearly in all simulated setups (see Figure 6 and Figure 7). The second observation as the injection duration is increased the NOx formation is decreased, this due to reduction in combustion efficiency and hence leads to lessening the in cylinder temperature. For example, at setup ( $5^{\circ} \mathrm{CA}-\mathrm{bTDC}$ to $20^{\circ} \mathrm{CA}$-aTDC), the injection started at $5^{\circ} \mathrm{CA}$ before TDC and continued till $20^{\circ} \mathrm{CA}$ after TDC, therefore the injection duration is $25^{\circ} \mathrm{CA}$, at this setup and at $3000 \mathrm{rpm}$ the NOx emissions is equal to $995.6 \mathrm{ppm}$ (see Figure 6). When increasing the injection duration to $30^{\circ} \mathrm{CA}$, the emissions reduces to $848.25 \mathrm{ppm}$, more reduction in emission can be achieved at the maximum injection duration $45^{\circ} \mathrm{CA}$ which is reached to $342.4 \mathrm{ppm}$. 


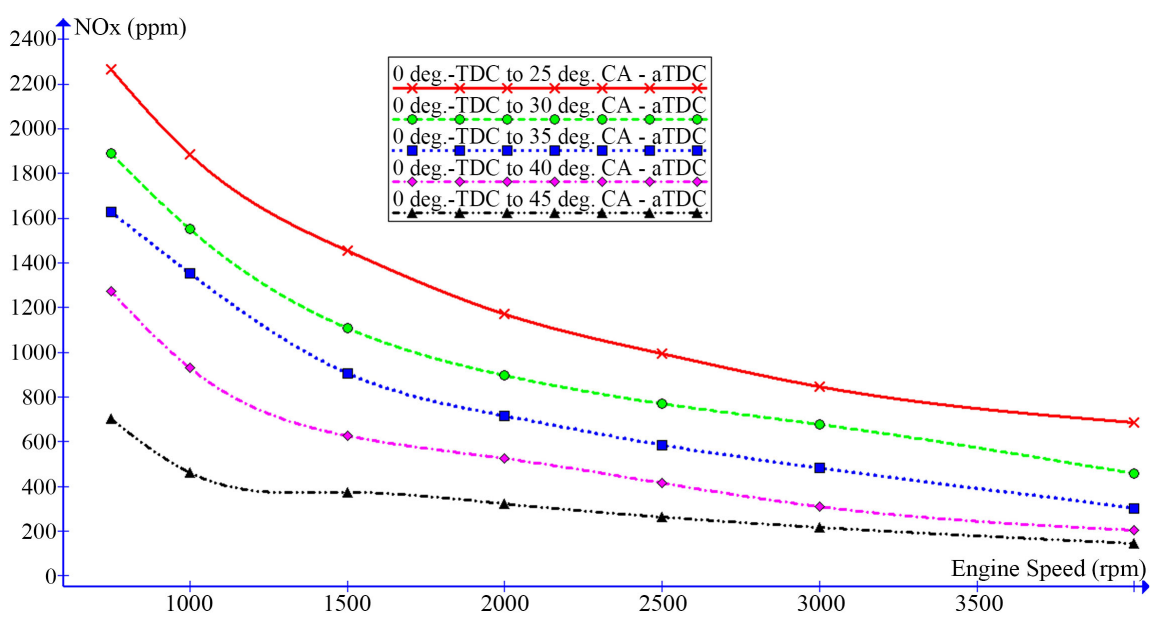

Figure 5. NOx emissions vs engine speed at $0^{\circ} \mathrm{CA}-\mathrm{TDC}$ injection timing and different injection durations.

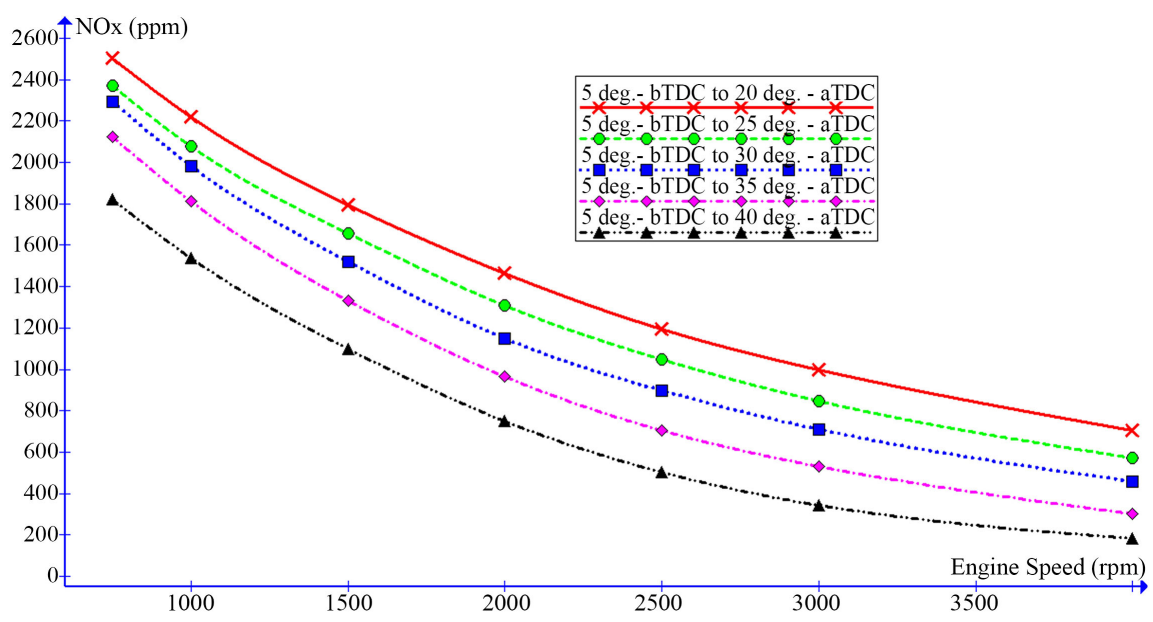

Figure 6. NOx emissions vs engine speed at $5^{\circ} \mathrm{CA}-\mathrm{bTDC}$ injection timing and different injection durations.

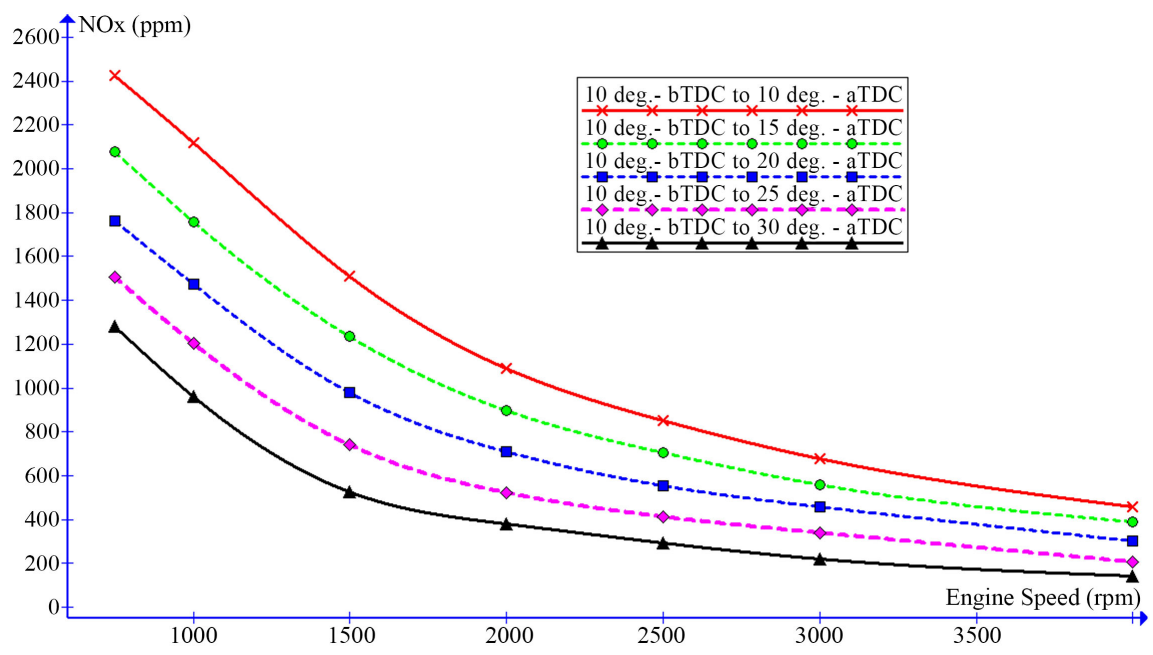

Figure 7. NOx emissions vs engine speed at $10^{\circ} \mathrm{CA}-\mathrm{bTDC}$ injection timing and different injection durations. 
A significant reduction in NOx emissions as the duration of injection increased (see Figures 5-7). The greater the injection duration the lesser the brake power the lesser the nitrogen oxides emissions (see Figures 1-3). The increasing of the injection duration far beyond definite limit some fuel will not get sufficient time to burn which is uneconomical and produces more emissions such as $\mathrm{CO}$ and UHCs as a result of incomplete combustion and excess injected fuel, while the nitrogen oxides decreases because the reduction of combustion efficiency. The optimum injection timing to obtain the great brake power is at the peak in-cylinder pressure, in case of less peak pressure (advanced or delay) leads to lower cylinder temperature and hence less brake power.

Figure 8 shows the maximum NOx emissions created by the three best setups regarding the brake power shown in Figure 4. The maximum NOx occurred at the setup $5^{\circ} \mathrm{CA}-\mathrm{bTDC}$ to $20^{\circ} \mathrm{CA}$-aTDC, while the best injection time setups to obtain extreme brake power started are at $5^{\circ} \mathrm{CA}-\mathrm{bTDC}$ and $10^{\circ} \mathrm{CA}-\mathrm{bTDC}$ (see Figure 4), therefore, the extreme brake power always accompanied by maximum NOx emissions. Figure 4 shows that the setup $10^{\circ} \mathrm{CA}-\mathrm{bTDC}$ to $10^{\circ} \mathrm{CA}$-aTDC can also achieve the same brake power as produced from setup $5^{\circ} \mathrm{CA}-\mathrm{bTDC}$ to $20^{\circ} \mathrm{CA}-\mathrm{aTDC}$, but less amount of NOx formation created when compared to the setup $5^{\circ} \mathrm{CA}-\mathrm{bTDC}$ to $20^{\circ} \mathrm{CA}-\mathrm{aTDC}$. Thus, the conclusion of this study is stated as, when the diesel engine used biofuel SME and after a deep investigation and discussion the injection profile $10^{\circ} \mathrm{CA}-\mathrm{bTDC}$ to $10^{\circ} \mathrm{CA}$-aTDC achieved the best brake power and less NOx emissions when compared to the other setups. Therefore, the best injection timing and injection duration of a diesel engine running on pure biodiesel SME is at $10^{\circ} \mathrm{CA}$-before TDC and $20^{\circ} \mathrm{CA}$ duration respectively. The fuel injection starts at $10^{\circ} \mathrm{crank}$ angle before top dead center during the compression stroke, and ends at $10^{\circ}$ crank angle after top dead center during the expansion stroke. The choosing process was based on the maximum power output and less quantity of NOx emissions.

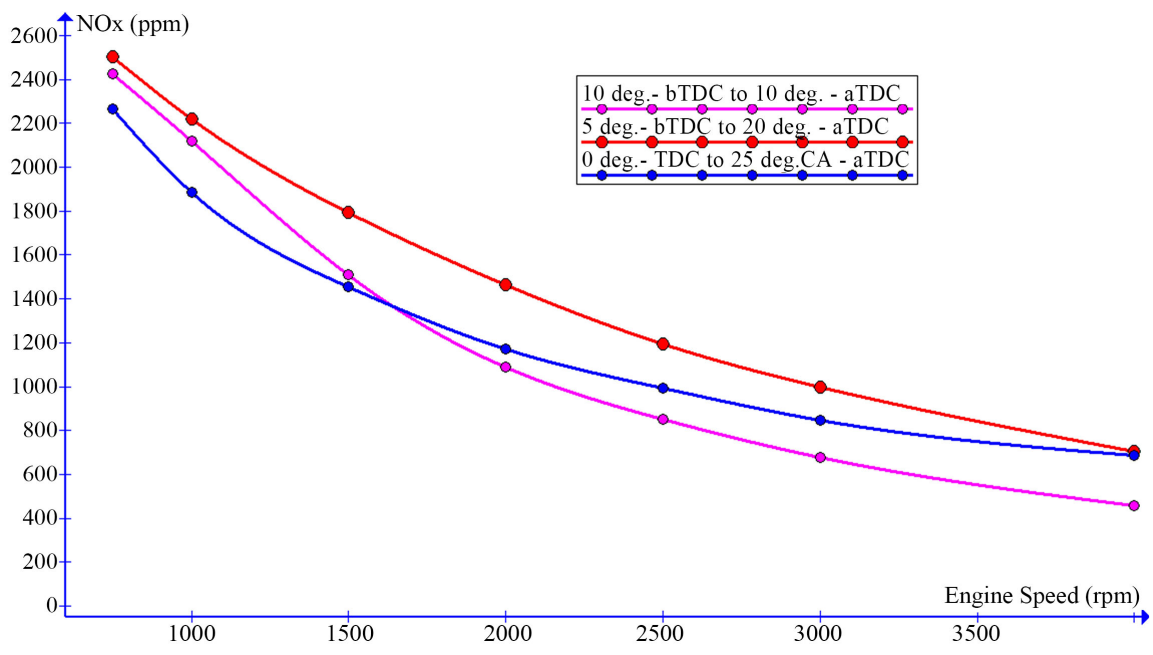

Figure 8. NOx emissions vs engine speed at different timing $0^{\circ} \mathrm{CA}-\mathrm{TDC}, 5^{\circ} \mathrm{CA}-\mathrm{bTDC}$ and $10^{\circ} \mathrm{CA}-\mathrm{bTDC}$ and different injection durations. 


\section{Conclusions}

Biofuels are renewable energy sources, prepared from carbon-based material, sugar or vegetable oils. Biofuels play a useful role in decreasing the emissions of carbon dioxide. The biofuels usage has grown-up quickly through the last years. This study is carried out to research the best injection timing and injection duration to obtain high engine performance and lesser nitrogen oxides emissions. Since the brake power is directly proportional to the emissions, Retarding or advancing the injection timing has an effect on the peak cylinder pressure. As the cylinder pressure increases, the combustion temperature tends to increase which result in more power and high NOx emissions. Additionally, there is an optimum injection timing that gives the best performance. From this investigation, the results can be summarized as follows:

1) The increase of brake power through advance fuel injection was due to high cylinder pressure and high heat rate.

2) Furthermore, the delay of the injection timing with suitable injection duration increases the engine brake power.

3) The NOx emission was reduced in the greater injection durations while the brake power decreased at those injection durations. Consequently, as the brake power increased the NOx emissions increased.

Therefore, to reduce the NOx emission it is recommending to introduce one of the techniques used to minimize the emissions to the engine fueled by biofuel such as Exhaust Gas Recirculation, oxidation catalysts (OC) or selective catalytic reduction (SCR) systems. Finally, the selection of the best injection timing and injection duration of diesel engine using $100 \%$ biofuel Soya Methyl Ester is considered as extra information in the field of using renewable energies.

\section{Acknowledgements}

The authors would like to thank the Deanship of Scientific Research, Qassim University for funding publication of this project. Finally, thanks to Professor Andrey Kuleshov (Moscow State Technical University) for allowed us to use the simulation software (diesel-RK).

\section{Conflicts of Interest}

The authors declare no conflicts of interest regarding the publication of this paper.

\section{References}

[1] Cetinkaya, M., Ulusoy, Y., Tekin, Y. and Karaosmanoglu, F. (2005) Engine and Winter Road Test Performances of Used Cooking Oil Originated Biodiesel. Energy Conversion and Management, 46, 1279-1291. https://www.sciencedirect.com/science/article/pii/S019689040400161X https://doi.org/10.1016/j.enconman.2004.06.022

[2] Agarwal, A.K. (2007) Biofuels (Alcohols and Biodiesel) Applications as Fuels for Internal Combustion Engines. Progress in Energy and Combustion Science, 33, 223-271. https://www.sciencedirect.com/science/article/pii/S0360128506000384 
https://doi.org/10.1016/j.pecs.2006.08.003

[3] Zheng, M., Mulenga, M., Reader, G., Wang, M., Ting, D. and Tjong, J. (2008) Biodiesel Engine Performance and Emissions in Low Temperature Combustion. Fuel, 87, 714-722.

https://www.sciencedirect.com/science/article/pii/S0016236107002670?via\%3Dihub https://doi.org/10.1016/j.fuel.2007.05.039

[4] Bhale, P., Deshpande, N. and Thombre, S. (2008) Improving the Low Temperature Properties of Biodiesel Fuel. Renewable Energy, 34, 794-800.

https://www.researchgate.net/publication/222043784_Improving_the_low_temperat ure_properties_of_biodiesel_fuel

[5] Barnwal, B.K. and Sharma M.P. (2005) Prospects of Biodiesel Production from Vegetable Oils in India. Renewable and Sustainable Energy Reviews, 94, 363-378. https://www.sciencedirect.com/science/article/abs/pii/S136403210400067X https://doi.org/10.1016/j.rser.2004.05.007

[6] Williams, J.B. (2002) Production of Biodiesel in Europe-The Markets. European Journal of Lipid Science and Technology, 104, 361-362.

https://doi.org/10.1002/1438-9312(200206)104:6\%3C361::AID-EJLT361\%3E3.0.CO;2-9

[7] Huang, Z., Shiga, S., Ueda, T., et al. (2003) Effect of Fuel Injection Timing Relative to Ignition Timing on the Natural-Gas Direct-Injection Combustion. Journal of Engineering for Gas Turbines and Power, 125, 783-790.

https://www.researchgate.net/publication/228544790_Effect_of_Fuel_Injection_Ti ming_Relative_to_Ignition_Timing_on_the_Natural-Gas_Direct-Injection_Combu $\underline{\text { stion }}$ https://doi.org/10.1115/1.1563243

[8] Oh, H. and Bae, C. (2013) Effects of the Injection Timing on Spray and Combustion Characteristics in a Spray-Guided DISI Engine under Lean-Stratified Operation. Fuel, 107, 225-235. https://www.sciencedirect.com/science/article/pii/S0016236113000288 https://doi.org/10.1016/j.fuel.2013.01.019

[9] Zeng, K., Huang, Z., Liu, B. et al. (2006) Combustion Characteristics of a Direct-Injection Natural Gas Engine under Various Fuel Injection Timings. Applied Thermal Engineering, 26, 806-813.

https://www.sciencedirect.com/science/article/abs/pii/S1359431105003364 https://doi.org/10.1016/j.applthermaleng.2005.10.011

[10] Nwafor, O.M.I. (2007) Effect of Advanced Injection Timing on Emission Characteristics of Diesel Engine Running on Natural Gas. Renewable Energy, 32, 2361-2368.

https://www.hindawi.com/journals/jc/2016/6501462/

https://doi.org/10.1016/j.renene.2006.12.006

[11] Mohammed, S.E., Baharom, M.B., Aziz, A.R.A. and Firmansyah. (2011) The Effects of Fuel-Injection Timing at Medium Injection Pressure on the Engine Characteristics and Emissions of a CNG-DI Engine Fueled by a Small Amount of Hydrogen in CNG. International Journal of Hydrogen Energy, 36, 11997-12006.

https://www.sciencedirect.com/science/article/abs/pii/S0360319911013231 https://doi.org/10.1016/j.ijhydene.2011.05.110

[12] Hagos, F.Y., Aziz, A.R.A., Sulaiman, S.A. and Firmansyah (2012) Combustion Characteristics of Late Injected CNG in a Spark Ignition Engine under Lean Operating Condition. Journal of Applied Sciences, 23, 2368-2375.

https://scialert.net/abstract/?doi=jas.2012.2368.2375 https://doi.org/10.3923/jas.2012.2368.2375

[13] Pulkrabek, W.W. (1997) Engineering Fundamentals of the Internal Combustion Engine. Prentice-Hall, New York. 
[14] Adam, I.K., Aziz, A.A.R. and Yusup, S. (2015) Determination of Diesel Engine Performance Fueled Biodiesel (Rubber Seed/Palm Oil Mixture) Diesel Blend. International Journal of Automotive and Mechanical Engineering, 11, 2675-2685.

https://www.semanticscholar.org/paper/DETERMINATION-OF-DIESEL-ENGINE -PERFORMANCE-FUELED-(-Adam-Aziz/79c0dd10098dafed3f762f2d47dd3772ab 8b9ef0 https://doi.org/10.15282/ijame.11.2015.44.0225

[15] Randazzo, M.L. and Sodré, J.R. (2011) Exhaust Emissions from a Diesel Power Vehicle Fuelled by Soybean Biodiesel Blends (B3-B20) with Ethanol as an Additive (B20E2-B20E5). Fuel, 90, 98-103.

https://research.aston.ac.uk/en/publications/exhaust-emissions-from-a-diesel-powe red-vehicle-fuelled-by-soybea https://doi.org/10.1016/j.fuel.2010.09.010

[16] Atmanli, A., Ileri, E. and Yuksel, B. (2014) Experimental Investigation of Engine Performance and Exhaust Emissions of a Diesel Engine Fueled with Diesel- $N$-Butanol Vegetable Oil Blends. Energy Conversion and Management, 81, 312-321. https://www.sciencedirect.com/science/article/pii/S019689041400168X https://doi.org/10.1016/j.enconman.2014.02.049

[17] Agarwal, A.K., Bijwe, J. and Das, L. (2003) Wear Assessment in a Biodiesel-Fueled Compression Ignition Engine. Journal of Engineering for Gas Turbines and Power, $125,820-826$.

https://asmedigitalcollection.asme.org/gasturbinespower/article-abstract/125/3/820/72 5034/Wear-Assessment-in-a-Biodiesel-Fueled-Compression?redirectedFrom=PDF https://doi.org/10.1115/1.1501079

[18] Kumar, N., Varun and Chauhan, S.R. (2016) Evaluation of the Effects of Engine Parameters on Performance and Emissions of Diesel Engine Operating with Biodiesel Blend. International Journal of Ambient Energy, 37, 121-135.

https://www.tandfonline.com/doi/abs/10.1080/01430750.2014.907208 https://doi.org/10.1080/01430750.2014.907208

[19] Khalid, A., Jaat, N., Sapit, A., Razali, A., Manshoor, B., Zaman, I., et al. (2015) Performance and Emissions Characteristics of Crude Jatropha Oil Biodiesel Blends in a Diesel Engine. International Journal of Automotive and Mechanical Engineering, 11, 2247-2257.

https://www.researchgate.net/publication/280495065_PERFORMANCE_AND_EMI SSIONS_CHARACTERISTICS_OF_CRUDE_JATROPHA_OIL_BIODIESEL_BLE NDS_IN_A_DIESEL_ENGINE

[20] Dzurenda, L., Hroncová, E. and Ladomerský, J. (2016) Extensive Operating Experiments on the Conversion of Fuel-Bound Nitrogen into Nitrogen Oxides in the Combustion of Wood Fuel. Forests, 8, 1. https://www.mdpi.com/1999-4907/8/1/1 https://doi.org/10.3390/f8010001

[21] Dangar, H. and Rathod, G.P. (2013) Combine Effect of Exhaust Gas Recirculation (EGR) and Varying Inlet Air Pressure on Performance and Emission of Diesel Engine. IOSR Journal of Mechanical and Civil Engineering (IOSR-JMCE), 6, 26-33. https://www.researchgate.net/publication/304417764_Combine_Effect_of_Exhaust_ Gas_Recirculation_EGR_and_Varying_Inlet_Air_Pressure_on_Performance_and_ Emission_of_Diesel_Engine https://doi.org/10.9790/1684-0652633

[22] https://diesel-rk.bmstu.ru/

[23] http://www.mitsubishilinks.com/fsm/pajero_fsm_printed-1990_engine_4D56-25-dies el.pdf 


\section{Nomenclature}

\begin{tabular}{cccc}
\hline aTDC & After Top Dead Center o CA & NREL & National Renewable Energy Laboratory \\
\hline bp & Brake Power kW & SCR & Selective Catalytic Reduction \\
bTDC & Before Dead Center o CA & SOI & Start of Injection \\
CA & Crank Angles o & SME & Soya Methyl Ester \\
$\mathrm{CO}_{2}$ & Carbon Dioxide ppm & ppm & part per million \\
DOC & Diesel Oxidation Catalysts & rpm & revolution per minute \\
EGR & Exhaust Gas Recirculation & HCs & Hydrocarbons \\
EOI & End of Injection & NOx & Nitrogen Oxides \\
\hline
\end{tabular}

\section{Appendix (A)}

\begin{tabular}{|c|c|c|c|}
\hline Injection Duration Crank Angle (CA) & $\begin{array}{l}\text { Engine Speed } \\
(\mathrm{rpm})\end{array}$ & $\begin{array}{c}\text { Brake Power } \\
(\mathrm{kW})\end{array}$ & $\begin{array}{c}\text { NOx Emissions } \\
(\mathrm{ppm})\end{array}$ \\
\hline \multirow{7}{*}{$10^{\circ} \mathrm{CA}-\mathrm{bTDC}$ to $10^{\circ} \mathrm{CA}-\mathrm{aTDC}$} & 750 & 9.8 & 2424 \\
\hline & 1000 & 15.9 & 2117 \\
\hline & 1500 & 28.9 & 1511 \\
\hline & 2000 & 40.8 & 1090 \\
\hline & 2500 & 52.2 & 852 \\
\hline & 3000 & 61.1 & 679 \\
\hline & 4000 & 73.3 & 456 \\
\hline \multirow{7}{*}{$10^{\circ} \mathrm{CA}-\mathrm{bTDC}$ to $15^{\circ} \mathrm{CA}-\mathrm{aTDC}$} & 750 & 9.5 & 2078 \\
\hline & 1000 & 15.67 & 1757 \\
\hline & 1500 & 27.4 & 1236 \\
\hline & 2000 & 39.6 & 897 \\
\hline & 2500 & 50.2 & 706 \\
\hline & 3000 & 58.4 & 559 \\
\hline & 4000 & 69.9 & 389 \\
\hline \multirow{7}{*}{$10^{\circ} \mathrm{CA}-\mathrm{bTDC}$ to $20^{\circ} \mathrm{CA}$-aTDC } & 750 & 8.3 & 1763 \\
\hline & 1000 & 15.2 & 1473 \\
\hline & 1500 & 26.8 & 980 \\
\hline & 2000 & 38.4 & 755 \\
\hline & 2500 & 48.5 & 589 \\
\hline & 3000 & 55.9 & 457 \\
\hline & 4000 & 64.9 & 301 \\
\hline \multirow{7}{*}{$10^{\circ} \mathrm{CA}$-bTDC to $25^{\circ} \mathrm{CA}$-aTDC } & 750 & 7.5 & 1507 \\
\hline & 1000 & 14.0 & 1202 \\
\hline & 1500 & 26.3 & 740 \\
\hline & 2000 & 37.9 & 522 \\
\hline & 2500 & 46.5 & 414 \\
\hline & 3000 & 52.1 & 340 \\
\hline & 4000 & 58.4 & 204 \\
\hline
\end{tabular}




\section{Continued}

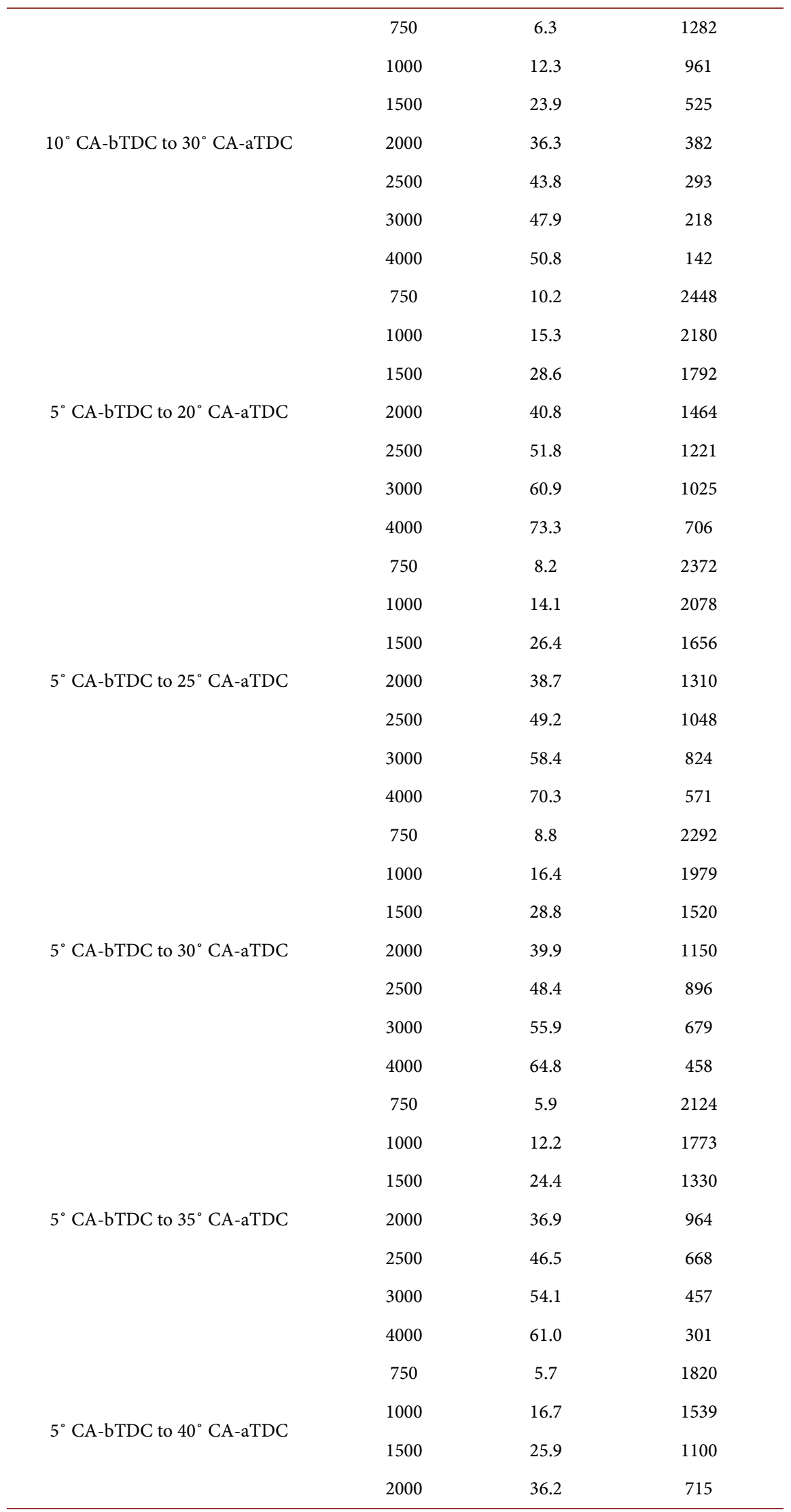




\section{Continued}

\begin{tabular}{|c|c|c|c|}
\hline & 2500 & 43.7 & 487 \\
\hline & 3000 & 47.9 & 342 \\
\hline & 4000 & 50.9 & 182 \\
\hline & 750 & 5.7 & 2267 \\
\hline & 1000 & 10.7 & 1887 \\
\hline & 1500 & 21.6 & 1456 \\
\hline \multirow[t]{7}{*}{$0^{\circ} \mathrm{CA}$-TDC to $25^{\circ} \mathrm{CA}$-aTDC } & 2000 & 32.0 & 1170 \\
\hline & 2500 & 39.7 & 993 \\
\hline & 3000 & 42.7 & 848 \\
\hline & 4000 & 36.2 & 686 \\
\hline & 750 & 10.2 & 1890 \\
\hline & 1000 & 16.1 & 1552 \\
\hline & 1500 & 28.7 & 1110 \\
\hline \multirow[t]{7}{*}{$0^{\circ} \mathrm{CA}$-TDC to $30^{\circ} \mathrm{CA}$-aTDC } & 2000 & 39.7 & 897 \\
\hline & 2500 & 50.2 & 770 \\
\hline & 3000 & 58.4 & 678 \\
\hline & 4000 & 69.9 & 458 \\
\hline & 750 & 10.3 & 1626 \\
\hline & 1000 & 16.4 & 1352 \\
\hline & 1500 & 28.5 & 906 \\
\hline \multirow[t]{7}{*}{$0^{\circ} \mathrm{CA}$-TDC to $35^{\circ} \mathrm{CA}$-aTDC } & 2000 & 38.9 & 715 \\
\hline & 2500 & 48.3 & 585 \\
\hline & 3000 & 55.9 & 481 \\
\hline & 4000 & 64.8 & 301 \\
\hline & 750 & 9.6 & 153 \\
\hline & 1000 & 17.2 & 929 \\
\hline & 1500 & 28.3 & 524 \\
\hline \multirow[t]{7}{*}{$0^{\circ} \mathrm{CA}-\mathrm{TDC}$ to $40^{\circ} \mathrm{CA}$-aTDC } & 2000 & 37.9 & 522 \\
\hline & 2500 & 46.5 & 414 \\
\hline & 3000 & 52.4 & 310 \\
\hline & 4000 & 58.4 & 204 \\
\hline & 750 & 9.7 & 701 \\
\hline & 1000 & 16.3 & 461 \\
\hline & 1500 & 27.9 & 372 \\
\hline \multirow[t]{4}{*}{$0^{\circ} \mathrm{CA}$-TDC to $45^{\circ} \mathrm{CA}$-aTDC } & 2000 & 37.3 & 382 \\
\hline & 2500 & 43.8 & 293 \\
\hline & 3000 & 47.9 & 217 \\
\hline & 4000 & 50.9 & 142 \\
\hline
\end{tabular}

